\title{
A BANALIDADE E O EXTRAORDINÁRIO NO COTIDIANO DE FILHAS E FILHOS DE MÃES LÉSBICAS
}

Mônica Fortuna Pontes (GEPSID/UERJ - m.fortunapontes@ gmail.com)

\begin{abstract}
RESUMO
A maioria das pesquisas e trabalhos realizados sobre famílias homoparentais são baseados naquilo que pessoas adultas relatam. Sejam profissionais da Medicina e da Psicologia, pensadores da Sociologia, da Antropologia e do Direito, sejam os próprios pais e mães. Filhas e filhos raramente fazem parte das produções sobre o assunto. O presente texto, no entanto, foi pensado e produzido a partir das narrativas de onze filhas e dois filhos de mães lésbicas naquilo que elas e eles enxergam de ordinário e extraordinário em suas famílias. A partir da cartografia realizada, serão discutidos alguns aspectos do que vem a ser "famílias como as outras", no contexto das homoparentalidades em sociedades heteronormativas, brasileira e francesa. Os relatos obtidos nas entrevistas apontam um cotidiano familiar feito de encontros, desencontros, desafios e trocas afetivas, ou seja, como ocorre nas múltiplas configurações familiares. Contudo, as semelhanças entre as famílias começam a borrar a partir das interações sociais dessas filhas e filhos, à medida que a vida privada se mistura com a pública. Assim, percebem que, aos olhos sociais, há diferenças nas semelhanças, há desigualdades entre suas famílias e a de colegas. No banal do dia-a-dia em família emerge o extraordinário da homoparentalidade. Nas entrevistas foram observadas repercussões distintas relacionadas aos caminhos percorridos, na busca por aquisição de direitos LGBT, judiciário no Brasil e legislativo na França. Assim, entre o ordinário e o extraordinário, essas/es filhas/os confrontam adversidades e as transformam em potência de reinvenção.
\end{abstract}

Palavras-chave: homoparentalidade; filhos; direitos LGBT

\section{THE BANALITY AND THE EXTRAORDINARY IN THE DAILY LIFE OF LESBIAN MOTHERS' DAUGHTERS AND SONS}

\begin{abstract}
Most researches about homoparental families are based on the adult's perspective - whether or not professionals from Medicine and Psychology, thinkers in Sociology, Anthropology and Law fields, or simply fathers and mothers - thus daughters and sons are barely heard in such investigations. This research includes the narratives of eleven daughters and two sons of lesbian mothers about what they set as the ordinary and extraordinary into their families. Based on a cartographic method, the research points what it would be "families like others" in the context of homoparentality into the heteronormative Brazilian and French societies. The interviews point to a family daily life of meetings, mismatches, challenges and affective exchanges, as it occurs in multiple family configurations. However, the similarities between the families begin to blur as from the social interactions of these daughters and sons, as private life blends with public life. Thus, they realize that in view of society, there are differences in similarities, there are inequalities between their families and their colleagues'. In the banality of everyday family life, the extraordinary of homoparentality emerges. In the interviews, distinct repercussions are related to paths related to the acquisition of LGBT rights, in the Judiciary Branch in Brazil and Legislative Branch in France. Between the ordinary and the extraordinary, these daughters and sons confront adversities and transform them into a potency of reinvention.
\end{abstract}

Keywords: homoparentality, daughters and sons; LGBT rights 


\section{INTRODUÇÃO}

A maioria das pesquisas e trabalhos realizados sobre famílias homoparentais é baseada no relato de pessoas adultas. Sejam profissionais da medicina, da psicologia, pensadores da sociologia, antropologia, do direito, sejam as próprias mães ou os próprios pais. Filhas e filhos raramente fazem parte das produções sobre o assunto. De acordo com o levantamento que Vecho \& Schneider (2005) realizaram, o ponto de vista das/os filhas/os ${ }^{1}$ sobre a situação familiar é pouco explorado nos estudos desenvolvidos. São sujeitos das pesquisas, sem serem os atores.

O presente texto, contudo, foi pensado e produzido a partir das narrativas de filhas e filhos de mães lésbicas, naquilo que elas e eles enxergam de ordinário e extraordinário em suas famílias. Os dados mencionados fazem parte de uma pesquisa maior, uma tese de doutorado. Tal trabalho é uma cartografia realizada com filhas e filhos de mães lésbicas, a partir de entrevistas individuais, entre 2016 e 2018, com seis filhas brasileiras, cinco francesas e dois filhos, um de cada nacionalidade, com idades entre 12 e 45 anos. Os encontros foram realizados tanto no Brasil quanto na França ${ }^{2}$, onde parte do doutorado se desenvolveu.

Rose $^{3}$, entrevistada francesa, 28 anos, branca, proferiu uma frase que explicita o terreno a ser explorado, ou seja, como a história de sua vida pode ser, ao mesmo tempo, extraordinária aos olhos da sociedade e banal aos seus próprios olhos. Extraordinária, no sentido do que é desconforme a ordem, e banal, no sentido de comum, habitual, ordinária: "É a minha vida, enfim, é totalmente normal. De fato, não há nada de... eu sei que é extraordinária, mas para mim é totalmente... é uma banalidade" (risos). Rose foi concebida com sêmen de doador anônimo, na França e criada por suas duas mães.

Os relatos ouvidos são unânimes em apontar um cotidiano familiar feito de encontros, desencontros, desafios e trocas afetivas entre seus membros, ou seja, como qualquer outra família. Contudo, as semelhanças parecem começar a borrar a partir das interações sociais

\footnotetext{
${ }^{1}$ Como a maioria das filhas e dos filhos entrevistadas/os é do sexo feminino, foi feita a opção de utilizar a palavra filha, no feminino, seguida da barra e do sufixo masculino quando fizer referência às/aos entrevistadas/os. Nas demais situações referentes às pessoas entrevistadas, para manter a coerência no texto, a mesma regra será adotada. ${ }^{2}$ No âmbito do Programa de Doutorado Sanduíche no Exterior (PDSE) com bolsa de estudos CAPES, durante 7 meses, em Paris.

3 A história de cada participante será apresentada, brevemente, na primeira vez que seus nomes forem mencionados. Como auxiliar para um melhor acompanhamento do texto, uma tabela com alguns dados das/os filhas/os foi inserida adiante. Todos os nomes são fictícios.
} 


\section{Nanduty}

ISSN:2317-8590

dessas filhas e filhos, à medida que a vida privada se mistura com a pública. Assim, percebem que, aos olhos sociais, há diferenças nas semelhanças, há especificidades, há desigualdades entre suas famílias e a de colegas. A rotina em família, em que a sexualidade das mães em nada importa para seus filhas e filhos, contrasta com o olhar externo e, muitas vezes, crítico lançado sobre essa mesma família, justamente devido à sexualidade de suas mães. Do comum, do banal, do ordinário que é o cotidiano de qualquer família, surge o extraordinário das famílias homoparentais. O extraordinário, enquanto não conformidade à ordem, é trazido pelo olhar social, pelo de fora. Como filhas e filhos, brasileiras/os e francesas/es vivenciam isso?

Observou-se nos relatos franceses o quanto sentiram-se atingidas/os pelas manifestações públicas contrárias às suas famílias, em 2013, quando das discussões que antecederam a legalização do casamento entre pessoas do mesmo sexo. Na França, a lei de abertura do casamento e da adoção aos casais do mesmo sexo, chamada lei do mariage pour tous (casamento para todos), foi promulgada em 2013. As manifestações contrárias à aprovação da referida lei aconteceram de forma muito intensas e homossexuais de modo geral, pais e mães gays e lésbicas, filhos e filhas de gays e lésbicas sentiram-se fortemente atacados. $\mathrm{O}$ fato de existirem parece poder ser tolerado, mas que ficassem no interior de suas casas, sem pleitearem igualdade de direitos. Dessa forma a dicotomia poderia se manter intacta.

Quando do debate em torno da referida lei, podia-se ler nos cartazes de manifestantes contra sua aprovação, alguns slogans como: "todos nascemos de um homem e de uma mulher", "um pai, uma mãe, nós não mentimos para nossas crianças", e ainda "casamento = um homem e uma mulher". Mobilizados por argumentos catastróficos provenientes da direita e da Igreja católica, unidas contra a aprovação do projeto de lei, os participantes expressavam suas convicções para salvar uma sociedade ameaçada de extinção, impedir que franceses/as pudessem vir a ser privados/as de um pai e de uma mãe e proteger as crianças de mentiras sobre suas origens (Gross: 2013). Como se possível fosse que duas mães ou dois pais se fizessem passar por genitoras/es.

As manifestações públicas contrárias foram sentidas como agressões e ofensas e assim relatadas por algumas/uns das/os filhas/os ouvidas/os. A diferença de suas famílias lhes foi explicitada e criticada em público, o que lhes impactou de forma particular, a partir da maneira como parte da sociedade francesa se posicionou.

No Brasil, filhas e filhos entrevistadas/os também relataram ter ouvido opiniões negativas sobre suas famílias. Contudo, o tipo de debate amplo, aberto e da magnitude dos 


\section{Nanduty}

ISSN:2317-8590

ocorridos na França, quando da discussão sobre a referida lei do casamento e, mais recentemente da lei da bioética, a qual regula os parâmetros para a procriação medicamente assistida (PMA) ${ }^{4}$, não fez parte do cenário brasileiro até então. Talvez por isso, a maioria das/os brasileiras/os entrevistadas/os não tenham relatado ter sofrido agressões diretas, o que não quer dizer que haja menos preconceito e discriminação no Brasil do que na França.

Assim, este artigo pretende, a partir da cartografia realizada, discutir certos aspectos do que vem a ser "famílias como as outras", no contexto das homoparentalidades em sociedades heteronormativas, brasileira e francesa, sob o prisma de filhas e filhos: percepções de que suas famílias são como as demais; a desnecessidade de falar sobre homossexualidade, e afins, em casa; a introdução do diferente através do olhar social e seus efeitos; e a produção de resistência.

Objetiva-se apontar e pensar a coexistência do banal e do extraordinário nas dinâmicas homoparentais, e nas relações que seus membros estabelecem com a sociedade. Ainda que não se pretenda um trabalho comparativo clássico, certas semelhanças e diferenças serão apontadas entre brasileiras/os e francesas/es, levando-se em conta para tal, os caminhos percorridos pelos dois países na busca por aquisição de direitos e os impactos disso na vida das/os filhas/os.

Além disso, será ressaltada a produção de resistência das/os filhas/os, por meio da potência de reinvenção, "[através] dos desvios necessários ao instituído, ampliando o horizonte para as múltiplas possibilidades existenciais" (Borges, 2019: 41).

\begin{tabular}{|l|l|l|c|c|}
\hline \multicolumn{1}{|c|}{ Nome } & Idade & Nacional. & Maternidades & Observação \\
\hline Carla & $16 \mathrm{a}$ & BR & mãe/madrinha & mãe=tia bio; pai faleceu \\
\hline Ana & $12 \mathrm{a}$ & BR & mãe/companh & adotada \\
\hline Lívia & $25 \mathrm{a}$ & BR & mãe/companh & viveu c pai até 8a e mantem contato \\
\hline Raquel & $32 \mathrm{a}$ & BR & duas mães & mãe=tia bio \\
\hline Bruna & $19 \mathrm{a}$ & BR & mãe/companh & pai faleceu \\
\hline Mathias & $20 \mathrm{a}$ & FR & mãe/companh & viveu c pai até 3a e mantem contato \\
\hline Adèle & $22 \mathrm{a}$ & FR & duas mães & PMA Bélgica DA $^{7}$ \\
\hline
\end{tabular}

\footnotetext{
${ }^{4}$ A procriação medicamente assistida (PMA) ou assistência medical à procriação (AMP), chamada no Brasil de reprodução assistida, é permitida na França somente para casais heterossexuais com problemas de infertilidade, até o momento. Tais procedimentos são regulados pela lei da Bioética, a qual está sendo revisada no momento. Sua votação final está prevista para esse início de ano ainda. A sociedade divide-se, mais uma vez, entre apoiadores e contrários à abertura da PMA para todas as mulheres.

${ }^{5}$ Em menção ao livro de Anne Cadoret (2014) "Des parents comme les autres. Homosexualité et parenté" (Pais e mães como os outros. Homossexualidade e parentesco).

6 Carla nomeia como "mãe" e "madrinha"/"dinda" as mulheres que a criaram. A escolha do nome "madrinha"/“dinda" teria sido uma saída do casal para que eventuais preconceitos não atingissem Carla, caso tivesse duas mães.

${ }^{7}$ Doador anônimo.
} 


\section{Nanduty}

ISSN:2317-8590

\begin{tabular}{|l|l|l|c|c|}
\hline Sophie & $19 \mathrm{a}$ & FR & duas mães $^{8}$ & PMA Bélgica DA \\
\hline Marion & $23 \mathrm{a}$ & FR & duas mães & adotada \\
\hline Juliette & $45 \mathrm{a}$ & FR & mãe/companh & contato com pai \\
\hline Rose & $28 \mathrm{a}$ & FR & duas mães & PMA França DA \\
\hline Carlos & $24 \mathrm{a}$ & BR & duas mães & pai faleceu \\
\hline Betina & $18 \mathrm{a}$ & BR & mãe/companh & ${\text { viveu c pai até 2 } 2^{\mathrm{a}} \text { e mantem contato }}^{\text {Tabela - homoparentalidades }}{ }^{10}$
\end{tabular}

\section{ENTRE O ORDINÁRIO E O EXTRAORDINÁRIO}

Inúmeros estudos realizados a partir da década de 1970 (Golombok et al: 1983; Flaks at al: 1995; Davis e Friel: 2001; Vanfraussen et al: 2002; Golombock et al: 2003; Maccallum e Golombock: 2004; Wainright et al: 2004; Wainright e Patterson: 2006; Goldberg: 2007; Fulcher et al: 2008) apontaram não haver diferenças significativas entre as famílias homoparentais e as famílias heteroparentais ${ }^{11}$ quanto ao desenvolvimento das/os filhas/os, ao envolvimento delas/es com seus pares e à orientação sexual. Contudo, ainda hoje, o argumento de que haveria prejuízos para filhas e filhos criadas/os fora do modelo heteroparental é usado.

No que diz respeito ao cotidiano familiar, em nada as famílias ouvidas através das/os filhas/os parece se diferenciar das demais no que tange aos desafios do dia a dia, aos anseios, afetos e trocas entre si. A homossexualidade das mães se apaga quando se trata do dia a dia em família. Por isso, talvez, as/os filhas/os digam que são iguais aos outros. Porque de fato são.

Côté et al (2019) realizaram estudo com 21 filhas e filhos de mães lésbicas no Quebec. Lhes foi perguntado em qual medida suas famílias são semelhantes ou diferentes das demais. Com idades entre 4 e 13 anos, o fator de diferenciação apontado pela maioria das filhas e filhos foi terem duas mães, mas não foi o único. Algumas/uns apontaram o funcionamento intrafamiliar, como por exemplo, a forma de amar as crianças ou a intensidade das punições; e a composição familiar, algumas têm muitos componentes. Um dos entrevistados disse, por exemplo, ter muitos avós. Ao serem perguntados sobre a implicação da diferença em suas vidas, as respostas foram na direção de que não haveria, ou que a diferença seria algo legal ou

\footnotetext{
${ }^{8}$ Sophie tem duas mães, ainda que, eventualmente, chame uma delas de madrinha, como poderá ser notado ao longo do texto.

${ }^{9}$ Rose tem duas mães, ainda que, em alguns momentos, chame uma delas de madrinha, como poderá ser notado ao longo do texto.

${ }^{10}$ A ordem dos nomes na tabela foi conforme a ordem em que as entrevistas foram feitas: cinco no Brasil, seis na França e, finalmente, duas no Brasil.

${ }^{11}$ Mesmo que tomemos o modelo heteroparental como referência, ressalto a importância de considerarmos a inexistência da família heteroparental universalizada (hooks: 1984).
} 


\section{Nanduty}

divertido. Uma participante mencionou que há consequências positivas, pois pode explicar aos colegas algo de especial que existe na sua família de duas mães, algo raro e "realmente diferente" (Côté et al. 2019: 134).

Raquel também ressalta o aspecto positivo do ser diferente. Raquel foi uma das entrevistadas brasileira, 32 anos, parda, viveu com suas duas mães desde seus primeiros dias de vida. Sua adoção por ambas foi formalizada recentemente. Uma das mães é sua tia biológica e a outra é ex-companheira da tia. Quando Raquel tinha aproximadamente 9 anos, ficou sabendo pelo primo que as mães formavam um casal. Apesar de ser criada por duas mulheres, isso não significava para ela que existia relação afetivo-sexual entre suas mães. Sua reação ao saber foi contar para suas melhores amigas e querer contar para todos na escola: "aí fiquei com vontade de contar na escola. Me deu uma onda dessa, vou contar que minhas mães são gays porque eu queria ser a diferentona".

Caio e Alex, dois gêmeos de 8 anos que fizeram parte da fase inicial da pesquisa de doutorado, mas que não entraram na análise das/os treze filhas/os aqui exposta ${ }^{12}$, ao olharem um livro onde havia vários desenhos de configurações familiares diversas, dentre eles, duas mães e dois pais com suas crianças, chamaram atenção para as famílias onde havia cães e gatos.

A forma como filhas e filhos encaram suas famílias não hegemônicas pode mudar ao longo de suas vidas e é atravessada por inúmeros fatores como, por exemplo, a idade. As narrativas acima foram dadas por filhas e filhos de até 13 anos. Ainda que suas famílias sejam retratadas pelas/os próprias/os como diferentes, não há conotação de inferioridade. Tal conotação acaba por ser trazida pelo olhar social, o que não significa que será incorporada desta forma por filhas e filhos.

Bruna, jovem brasileira de 19 anos, parda, que sempre viveu com sua mãe e companheiras, diz o seguinte:

Bruna - Eu já estou acostumada. Eu cresci com isso, pra mim é uma coisa muito normal, não vejo diferença [...] desde que eu me lembro. Meu pai faleceu, eu tava na barriga da minha mãe, então. A minha mãe, depois do meu pai, ela só teve um namorado [...]. Minha mãe foi casada durante 12 anos com uma mulher que eu considero da minha família, que me criou desde muito novinha. Minha mãe conheceu ela eu tinha 1 ano e pouquinho, então.

\footnotetext{
${ }^{12}$ Numa fase inicial, a pesquisa de doutorado seria feita com crianças. Com o desenrolar do trabalho foi feita a opção de incluir somente entrevistadas/os a partir dos 12 anos de idade.
} 
Sophie, francesa de 19 anos, branca, com duas mães e que nasceu por reprodução assistida na Bélgica, assim como sua irmã, demonstrou não considerar sua família distinta das demais:

Mônica - Pode me contar sua história familiar, principalmente a relação entre vocês quatro?

Sophie - Tenho a impressão de não haver diferença, de fato, em relação aos outros [...], na verdade as dificuldades que podemos encontrar, nunca pensei que estivessem ligadas à homossexualidade. Somos muito próximas, nós quatro. Nós ficamos atentas umas às outras, porque nossa família extensa não é terrível (risos), mas não é a melhor família do mundo. Então formamos laços fortes entre nós quatro [...].

Contudo, há um componente que marca a diferença numa sociedade cisheterocentrada e se faz presente, que é a homossexualidade de suas mães. Seria esse um assunto merecedor de ser tratado em família?

Observou-se, entre as/os entrevistadas/os, que a homossexualidade das mães é vista como um tema dado, que não requer problematizações. Rose e Sophie relatam:

Mônica - Os assuntos homoparentalidade e homossexualidade eram assuntos entre vocês três? Vocês falavam sobre isso? Você fazia perguntas, em algum momento da sua vida?

Rose - Não, porque era realmente alguma coisa banal, de fato.

Mônica - Nesse momento [das manifestações da manif pour tous ${ }^{13}$ ] você falava com a sua mãe e sua madrinha sobre essa situação?

Sophie - Não, não falávamos, isso estava por todos os lados, nos jornais [...]. Nós não falávamos especificamente. Mas não era um assunto tabu, de fato. Se eu fizesse perguntas, elas respondiam. Não, não era tabu na minha casa, mas a gente não falava. Era normal, era como se a gente começasse a falar porque as cadeiras são as cadeiras.

Mas a que serve a colocação, por parte dessas/es filhas/os, da homossexualidade de suas mães num lugar de banalidade? Tratar dessas situações no âmbito familiar seria se aproximar do assunto (homo) sexualidade de suas mães?

Quais questionamentos, as narrativas acima podem suscitar? O que significaria conversar sobre homossexualidade ou homoparentalidade em casa? Para Rose e Sophie, parece que a obviedade do assunto não requer explicação. Estariam elas tão harmonizadas com suas configurações familiares que não haveria espaço para problematizações? Tais assuntos trariam, de certa maneira, a sexualidade das mães para a cena familiar. Levantar questionamentos

\footnotetext{
${ }^{13}$ La manif pour tous é um coletivo de associações e potente organizador das manifestações contrárias ao casamento entre pessoas do mesmo sexo, ou à extensão da PMA para casais de lésbicas ou mulheres solteiras na França.
} 


\section{Nanduty}

ISSN:2317-8590

significaria falar da sexualidade das mães, algo que não se costuma fazer? Não falar seria, ainda, uma forma de poupar suas mães e a si próprias, protagonistas de tantos debates sociais preconceituosos?

Ainda que relatem que tais assuntos não são merecedores de serem tratados nas conversas em família, devido à trivialidade neles contida, a homossexualidade é uma estrangeira numa sociedade heterocêntrica, e traz a sexualidade das mães à tona em algum instante. Situação que tem desdobramentos.

De acordo com as narrativas, num primeiro momento de suas vidas, diferenças inexistiam entre suas famílias e as demais. Com o passar dos anos, tais diferenças foram sendo percebidas através do olhar social:

Sophie - [...] para mim é uma família normal. Não é particularmente diferente das outras. Justamente porque não falamos [em casa sobre a própria família], e isso parece natural. Eu não sei... Então, isso me ajuda a falar mais facilmente [sobre minha família] com os outros, como se eu tivesse a impressão de que é alguma coisa de normal [...]. Depois, quando cresci, percebi que existem diferenças.

Mônica - Quando você começou a perceber que havia diferenças?

Sophie - Na verdade a diferença é sobretudo a diferença aos olhos da sociedade.

Quando o ambiente doméstico é atravessado pelas normas sociais, aspectos nada banais começam a surgir. $\mathrm{O}$ olhar do outro traz o extraordinário contido na banalidade de seus cotidianos.

Quando da discussão francesa sobre o projeto de lei do mariage pour tous, fazendo parte do longo percurso até a aprovação da lei, duas filhas e dois filhos de gays e lésbicas deram seus testemunhos ${ }^{14}$ na Assembleia Nacional Francesa. Estavam cientes da importância de serem ouvidos e, ainda que saibamos que eram discursos prontos, preparados para mostrar que vai tudo bem com elas e eles, é interessante notarmos o tom de alguns relatos. Transpareciam certa ironia, por vezes, ao narrarem histórias corriqueiras de lares, afetos e vínculos familiares, enquanto testemunhavam, em cadeia nacional, somente pelo fato de suas/seus mães/pais terem relações homossexuais. Essa cena estampa o privado entrelaçado ao público, ao mesmo tempo em que separados por um abismo. O poder público decidindo sobre o particular das famílias, sobre uma mãe poder ou não casar com sua com sua companheira ou adotar a própria filha.

A homossexualidade traz à tona a sexualidade dessas mães por estar fora da norma. Os desdobramentos disso na vida dessas/desses filhas/os são relatados, por vezes, como não

\footnotetext{
${ }^{14}$ Os testemunhos podem ser vistos em: http://www.regards.fr/web/enfants-d-homos-leurs-paroles-a-1,6124
} 


\section{Nanduty}

relevantes. Na dinâmica familiar interna, narram laços afetivos fortes entre os seus membros, conflitos e discussões existentes em qualquer lar, discordâncias e concordâncias. Contudo, outros tipos de desdobramentos, esses não tão inócuos, começam a surgir mais nitidamente na relação dessas/desses filhas/os com o meio social. Isso tornaria essas famílias ou essas/esses filhas/os diferentes por tabela?

Diante da participação/inserção de todos/as nós na heteronormatividade, quando essas/esses filhas/os se reportam ao fato de serem iguais ou diferentes, entende-se que estejam se referindo à família heteroparental. É este o modelo de referência em que está o reconhecimento social.

Para Rose, sua família é igual, porém diferente, desde sempre. Ainda que dito que homossexualidade e afins não foram assuntos discutidos em casa, sugere, no relato a seguir, que a diferença era explicada por suas mães:

Mônica - Quando você começou a perceber que a família de seus colegas não era como a sua? Ou você acha que as famílias são todas iguais? Houve um momento em que você se deu conta de que a família deles não era como a sua?

Rose - Acho que elas [mães] sempre me explicaram, explicaram muito, falamos muito, eu sempre soube que éramos diferentes, eu encontrava [entre seus colegas] raramente esse tipo de organização familiar...

Em outro momento completa que sempre soube haver algo que não devia ser dito para todo mundo:

Rose - Então, eu cresci numa região parisiense num primeiro momento [...], é verdade que sabíamos que éramos uma família particular, na medida em que tinha um tabu, [...] evitar falar, prestar atenção... mais tarde [quando as mães se separaram] me mudei com a minha mãe biológica para a Normandia, foi isso. Mas nós sempre fomos muito ligadas apesar da distância, como filhos de pais e mães divorciados. Muito próximas...

Talvez possamos pensar em quais situações o diferente de suas famílias é merecedor de ser um assunto em casa. Pode-se entrar em temas que tocam a homoparentalidade, sem que a (homo)sexualidade das mães seja diretamente explicitada. Por exemplo, quando se diz para uma criança que existem vários tipos de famílias, dois pais, duas mães, uma mãe, avós que criam seus netos e netas, e assim por diante, não há menção à sexualidade. Ainda que estejamos nos referindo ao diferente como sendo a homossexualidade das mães, a conexão entre ter duas mães e ter mães lésbicas que são um casal, vem com o tempo, com a idade.

Rose ressalta que as mães "explicavam muito", "falavam muito" e ela era consciente do tabu existente, de que havia necessidade de atenção, ou seja, sempre soube que, de certa forma, 


\section{Nanduty}

ISSN:2317-8590

eram diferentes. Possivelmente, o assunto ganha relevância à ponto de ser tratado em casa, quando diz respeito a preparar as/os filhas/os para o mundo. E essa é uma preocupação clara de muitas famílias. Ressaltar a diferença pode ter sido uma forma das mães de Rose prepará-la para o que iria enfrentar, fazendo parte de uma família de duas mães e sem pai.

Rose, mesmo após ressaltar a diferença existente entre sua família e outras que conhece, busca o paralelo com filhas/os de casais divorciados, algo tão comum hoje em dia, impactante no passado, mas completamente incorporado, apontando, assim, novamente em direção a algo banal - em direção a uma normalidade.

Nessa incessante dinâmica de ser igual e diferente de um determinado modelo familiar, Sophie e Mathias afirmam que famílias são distintas entre si e guardam singularidades. Mathias é um rapaz francês de 20 anos, que viveu desde criança com sua mãe e companheiras, e tem vínculo com o pai biológico. Para ambos, as distinções não seriam baseadas nas sexualidades de seus componentes:

Sophie - Eu tendo a pensar que as famílias são diferentes de uma para outra e não diferentes de uma sexualidade para outra.

Mathias - Existe diferença, mas todo mundo tem diferenças. Uns tem os pais separados, outros são originários da Ásia, outros são muçulmanos, outros cristãos, todos temos diferenças, mas não é por isso que somos malucos ${ }^{15}$. De fato, somos como muitas famílias.

Bruna cresceu convivendo com os namorados e namoradas de suas tias bissexuais, nas reuniões e festas familiares. Ela recorre ao exemplo de sua família "complicada", segundo suas palavras, por ter tantas lésbicas, ao mesmo tempo que ressalta a normalidade disso. E podemos pensar se a normalidade das famílias não se encontra, justamente, no quanto são complicadas:

Bruna - Minha família é um pouco complicada, não complicada, mas diferente desse padrão. Minha bisa [bisavó] teve 7 filhos, 1 homem e 6 mulheres. Dessas 6 mulheres, 4 são bi [bissexuais] [...]. Mas, assim, eu já estou acostumada. Eu cresci com isso, pra mim é uma coisa muito normal, não vejo diferença.

Sophie narra alguns conflitos em suas famílias, mas os descolam da homossexualidade de suas mães:

Sophie - O relacionamento com minhas mães é às vezes um pouco caótico

Mônica - o que é caótico?

Sophie - elas se desentendem facilmente, eu e minha madrinha discutimos facilmente também, isso influenciou nas minhas relações com outras pessoas, nos namoros. [...]

\footnotetext{
${ }^{15}$ Referência a algumas das agressões ouvidas durante as manifestações contra a lei do mariage pour tous.
} 
mas tem a ver com o impacto da relação das minhas mães entre elas e não do fato de serem homossexuais

Mônica - O tema está sempre presente, não? [...] por exemplo, você diz, não é por causa da sexualidade, é por causa do jeito de ser

Sophie - Sim. Na verdade, tenho a impressão de ser obrigada... tenho minha psicóloga, é minha psiquiatra, que frequentemente traz de volta esse assunto, e cada vez eu quero dizer a ela que a homossexualidade das minhas mães nunca foi um problema, nunca teve um impacto negativo... o único impacto negativo que pode ter é como minhas mães são como pessoas. Porque sim, os aspectos negativos de nossos pais e mães têm um efeito sobre nós, na verdade, à cada vez tenho a impressão de que, na verdade, tenho dificuldade em entender, que possamos pensar que são tão diferentes assim e que possamos dizer que "ah, seus defeitos são pelo fato de serem homossexuais". É somente que são pessoas, seres humanos diferentes uns dos outros, elas têm falhas como qualidades $[. .$.

Sophie chama a atenção para o quanto precisa ressaltar a desconexão entre a sexualidade de suas mães e eventuais problemas em sua vida, talvez porque ainda vigore essa crença de que a homossexualidade de mães tenha efeitos nefastos na vida de filhas e filhos. Ela não deixou de relatar episódios que podem ocorrem em qualquer família, contando que se desentendem em casa, que frequenta uma psiquiatra, toma remédios e tem altos e baixos na vida. Ainda assim, acha importante fazer a ressalva de que a homossexualidade das mães é inocente. Talvez isso possa significar uma forma de proteção da família, das mães e dela própria, uma vez que são tão atacadas e certos episódios com frequência são interpretados como decorrentes da homomaternidade, para usar um termo de Rozée (2012).

Carla, brasileira, 16 anos, parda, criada por sua mãe, que é sua tia biológica ${ }^{16}$, e por sua madrinha, ex-companheira da mãe, aponta para a normalidade dos membros de sua família fazerem terapia, e para a dificuldade de encontrar configurações familiares semelhantes à sua:

Carla - Eu sempre fiz terapia [...] minha mãe e minha dinda fizeram sempre muita terapia. É normal fazer terapia nessa família (risos)

Mônica - Não é aquela família que acha que [terapia] é coisa de doido ...

Carla - Aqui essa família é tudo coisa de doido (risos)

Mônica - Por quê? Por que é diferente?

Carla - É [...], ninguém com uma história assim [uma mãe e uma madrinha lésbicas].

Se tem as pessoas não contam. É mais fácil ter um tio ou uma tia que são gays [...]. Podem ter um pai que se revela gay, mas não contam. Todos os meus amigos têm pai e mãe

Mônica - Você acha que eles são mais felizes por isso?

Carla - Não. Tantos problemas quanto.

\footnotetext{
${ }^{16} \mathrm{O}$ genitor de Carla morreu quando ela tinha 2 meses e sua genitora tem problemas mentais.
} 


\section{Nanduty}

Carla acrescenta que os problemas existem indiscriminadamente, não escolhendo um tipo familiar ou outro. Contudo, quando surgem nas famílias tidas como famílias modelo, aquelas com pai, mãe e filhas/os biologicamente concebidas/os, eles não são vinculados à sexualidade de pais e mães.

Lívia foi a única filha que expôs grande incômodo com a situação vivida, durante anos em sua casa, entre mãe, companheira da mãe e ela própria. Lívia conviveu com sua mãe e a companheira dela dos 8 anos, quando seu pai e mãe se separaram, até a idade adulta. Uma convivência difícil e marcada por segredos ligados à união homossexual da mãe, e por pouca afinidade entre Lívia e a companheira da mãe: "Pra mim foi muito traumático, não tenho uma boa experiência com o relacionamento de duas mulheres, crescer dentro de uma casa onde tem isso, entendeu?". Para Lívia, a companheira da mãe nunca foi considerada da família e quase nada do que viveu em sua casa foi compartilhado com colegas. Tinha muito medo daquilo que poderiam pensar. Nada foi banal naquele lar.

Para a maioria das/os filhas/os entrevistadas/os, a diferença aos olhos alheios, e que remete à homossexualidade das mães, parece não ter gerado estranhamento em casa, nem ter sido motivo para questionamentos junto às mães. Tomar como banal a homossexualidade de suas mães ou a homoparentalidade de suas famílias pode representar a normalidade sentida, no cotidiano familiar. Ao mesmo tempo, a particularidade familiar faz com que tenham suas vidas mais olhadas e/ou atacadas. Seriam diferentes dimensões da construção da banalidade?

A sexualidade nas famílias, de um modo geral, estaria inserida na lógica múltipla das interdições e de fazer falar do sexo constantemente, uma vez que sexo fala da verdade das pessoas, fazendo operar o dispositivo da sexualidade (Foucault: 1988). Dispositivo entendido aqui como: "um conjunto decididamente heterogêneo que engloba discursos, instituições, organizações arquitetônicas, decisões regulamentares, leis, medidas administrativas, enunciados científicos, proposições filosóficas, morais, filantrópicas (Foucault, 1979: 244). A homossexualidade, inserida na mesma lógica, obviamente, cumpriria função específica, a de manter ocupado o lugar dos excluídos. Como o dispositivo da sexualidade se apresentaria no âmbito da luta por direitos familiares?

\section{DESDOBRAMENTOS DAS MANIFESTAÇÕES NA FRANÇA}

Rose viveu com suas mães até completar 6 anos de idade, quando o casal se separou. Passou a morar com uma delas, a mãe biológica, mas nunca perdeu contato com sua madrinha, 


\section{Nanduty}

ISSN:2317-8590

maneira como, às vezes, chama a mãe que não a gerou, mas sempre a desejou. Em 2007, quando tinha 17 anos, sua mãe não-biológica faleceu. As mães não haviam se casado no papel, pois não era algo permitido até 2013 na França, assim como sua madrinha não possuía vínculo legal com a própria filha. Rose diz que se a madrinha ainda estivesse viva, gostaria de ser adotada por ela. Os acontecimentos dentro da família de Rose e a dinâmica em si, em nada diferem das demais famílias, segundo ela própria. Todavia, na esfera dos direitos, a cena é outra.

Quando das manifestações a favor do mariage pour tous, na França, parte considerável da sociedade pediu igualdade no acesso aos direitos. Homossexuais apareceram em massa, tanto nas manifestações quanto na mídia e nos debates, num período de revelação da face pública que deveria, segundo alguns, permanecer secreta. Gays e lésbicas, com ou sem famílias e filhas/os, saíram do silêncio da vida privada e as dicotomias privado/público, dentro/fora, interior/exterior se mostraram como frágeis separações.

Argumentar que homossexuais devam ter direito à uma vida livre, porém privada, é considerar que a vida pode ser vivida sem reconhecimento social. Tolerância para com gays e lésbicas deve haver, sim, acesso aos direitos iguais, não?

Conforme Fassin (2008), desde os debates sobre o Pacto Civil de Solidariedade $(\mathrm{PaCS})^{17}$, ninguém gostaria de ser visto como homofóbico e todos gostariam de combater a homofobia, tanto os de direita quanto os de esquerda, principalmente depois da aprovação do PaCS e com o apoio da opinião pública. Contudo, esta suposta vontade de combater a homofobia não impedia que a questão da desigualdade em relação ao casamento e à família, endossada implicitamente pelo Estado, ficasse clara. Segundo Borrillo (2010: 24):

Se a homofobia afetiva (psicológica) caracteriza-se pela condenação da homossexualidade, a homofobia cognitiva (social) pretende a diferença homo/hetero; neste aspecto, ela preconiza a tolerância, forma civilizada da clemência dos ortodoxos em relação aos heréticos. Neste último registro, ninguém rejeita os homossexuais; entretanto, ninguém fica chocado pelo fato de que eles não usufruam dos mesmos direitos reconhecidos aos heterossexuais.

Mathias, de 20 anos, ainda hoje avalia quem pode saber, ou não, sobre sua configuração familiar, acha que as pessoas podem "reagir de forma bizarra": "Quando se vê as reações que houve antes do mariage pour tous... Há pessoas com o olhar virulento sobre a homossexualidade".

\footnotetext{
${ }^{17}$ Pacte Civil de Solidarité. Na França, em 1999, mediante alteração do código civil, foi criado o PaCS, autorizando duas pessoas do mesmo sexo ou de diferentes sexos a firmarem contrato para "organizar sua vida em comum" (Dias, 2009: 66).
} 
Em outros dois momentos da entrevista, Mathias retoma os comentários ouvidos por ocasião das manifestações em torno da lei do mariage pour tous:

Mônica - quando você era pequeno, ou mais jovem, você já passou por situações difíceis devido à homossexualidade de sua mãe?

Mathias - sim, isso aconteceu porque tinha gente que, quando eu dizia que minha mãe era homossexual, eu pensava que não aconteceria nada... e hoje não somos mais amigos [devido a reação negativa que tiveram]. Isso aconteceu quando eu era pequeno. Depois quando eu estava um pouco mais velho, durante o mariage pour tous, foi muito duro porque havia muitos comentários feitos na escola. Eu me lembro de um debate organizado pela professora e eu me lembro das pessoas que disseram coisas horríveis sobre os homossexuais. Eu tinha o que? eu tinha 12 anos. Não, talvez mais, 14 anos. Eram coisas que eles tinham ouvido na rádio, ouvido dos seus pais, não eram coisas que eles diziam por eles mesmos. Mas quando ouvimos, no fundo de nós, eu ficava doido, quando eles diziam que os filhos dos homossexuais eram tarados, eu tinha vontade de dizer: "não, olha, eu não sou maluco!". Só que eu não dizia. Eu não queria me "queimar".

Mônica - existe alguma coisa que seja importante para você sobre essa questão [homoparentalidade/homoparentalidade], algo que seja importante a ser dito sobre o assunto?

Mathias - tem uma coisa que seria boa, principalmente quando vejo as pessoas que são contra o mariage pour tous, em especial lhes dizer que passem uma semana com uma família homossexual, homoparental e verão por quê. Muita gente, justamente, durante essa discussão do casamento dizia que os filhos de homossexuais eram desequilibrados, infelizes, sentiriam falta das referências, tudo que é contra, sem nunca terem conhecido uma família homoparental, e justamente lhes dizer para passar uma semana que seja e verem como os filhos são criados, da mesma maneira que os filhos de famílias heterossexuais, que são amados da mesma maneira. E nós não somos malucos.

A entrevista com Mathias foi a primeira a ser realizada na França, após cinco feitas no Brasil $^{18}$. Mas não havia aparecido até a conversa com Mathias, durante os encontros brasileiros, nada que se assemelhasse às reações francesas. Mas os efeitos dos debates públicos estiveram presentes na fala das/os francesas/es desde a primeira entrevista na França. Tal questão, trazida por Mathias, não fazia parte do hall de assuntos a serem abordados ${ }^{19}$. Interessante como as referências de nossos próprios países se fixam e a imersão na França auxiliou, justamente, no deslocamento de algumas questões que acabam por ser dadas como naturais.

A perspectiva cartográfica nos permite conduzir a pesquisa de forma que o campo de pesquisa seja construído durante a caminhada, sem definições prévias, e sim com

\footnotetext{
${ }^{18}$ Primeiramente foram realizadas cinco entrevistas no Brasil, em seguida seis na França e, posteriormente, mais duas no Brasil.

${ }^{19}$ Ainda que os assuntos das entrevistas não sejam fixos, alguns compõem um modelo de entrevista semiestruturada, que serve mais como auxiliar durante os encontros e menos como script a ser seguido.
} 


\section{Nanduty}

ISSN:2317-8590

possibilidades. A cartografia se apresenta como um campo de multiplicidades (Zambenedetti e Silva: 2011) onde é possível que se vá além do objetivo e do óbvio, e que se revisitem os platôs invisíveis para o olho-do-visível (Rolnik: 2014). Sendo "a realidade a ser investigada composta de processos e não só de objetos (coisas e estados de coisas) delimitados por contornos precisos e atemporais" (Tedesco et al. 2013: 300), buscou-se a aproximação aos processos das/os participantes através das entrevistas, encarando-as como uma conversa, conforme colocada por Deleuze e Parnet (1998), como experiências compartilhadas, sem roteiro fixo a ser seguido.

Assim, de forma semelhante a que aconteceu com Mathias, Sophie trouxe o assunto. Durante nosso diálogo, ela mencionou que em determinado momento entendeu que existia diferenças, e seguiu a conversa dizendo que se sentiu ferida durante as manifestações contrárias à lei do casamento:

Sophie - [...] eu me dei conta no momento da manifestação contra a família, principalmente... me senti ferida.

Mônica - em 2012?

Sophie - um pouco depois. [...] Naquela época, percebi que ainda existia uma parte da sociedade que achava que o modo de funcionamento da minha família não era normal (risos). É um absurdo. Naquele momento tinha um monte de cartazes contra a PMA ${ }^{20}$. Tenho a impressão de que colocavam palavras na minha boca. Eu estou muito bem sem pai, então não vejo por que outros filhos não poderiam estar. Naquele momento me dei conta de que as pessoas falavam sem saber, as pessoas no ensino médio, muito conservadoras, católicos... Mônica - em Rennes ${ }^{21}$ ?

Sophie - sim, em Rennes, na mesma escola que minha irmã, tinha pessoas que usavam camisetas da manif pour tous. Eu não entendia por que, se eles não me conheciam, eles não conheciam minhas mães e eles tinham essas ideias de que elas eram desse jeito. Parece absurdo para mim. De fato, é preconceito. Então percebi que tinha uma diferença para a sociedade.

Sophie, que na época das manifestações contra o mariage pour tous tinha 14 anos, se disse com raiva e, em certos momentos, cansada, como se estivesse no limite devido ao que ouvia na escola sobre a manif pour tous e começou a fazer sua própria pesquisa na internet, encontrar comunidades LGBT e ler sobre o assunto. Um pouco mais tarde descobriu o significado de ser uma militante. Hoje se considera uma militante individual, ou seja, não faz parte de nenhuma associação, mas se interessa pelo assunto diversidade sexual, de gênero e

\footnotetext{
${ }^{20}$ Em 2018, era possível a leitura de pichações nas calçadas de Paris com os dizeres “'Á part d'un pere, je ne manque de rien. PMA sans père, douleur sans fin". Tradução nossa: "Exceto um pai, não sinto falta de nada. PMA sem pai, dor sem fim”.

${ }^{21}$ Cidade francesa onde passou um período de sua vida.
} 


\section{Nanduty}

ISSN:2317-8590

discute sobre isso com sua irmã, com seus/suas amigos/as. Quando há manifestações procura se inteirar e, assim, decidir se participará ou não. Comenta que suas mães se frustraram bastante com as reações adversas ao casamento, mas que nunca foram militantes, e ressalta: "nós acordamos, nos demos conta que havia um problema, que a sociedade não nos aceitava como normais, mas não fizemos mal a ninguém...”.

Adèle, irmã de Sophie, 22 anos, branca, nascida de reprodução assistida na Bélgica e criada pelas duas mães, também expressou o quanto foi tocada pelas manifestações contra o mariage pour tous. Ela contou que sofreu bastante quando descobriu o que as pessoas pensavam sobre sua família e que não foi capaz de permanecer tranquila quanto a isso, tendo sido um momento de mudança em sua vida. Tornou-se militante em defesa da família homoparental, enquanto suas mães "só queriam levar uma vida sossegada em Rennes". Relata o quanto se sente bem na associação LGBT da Sciences $P o^{22}$, onde estuda em Paris. Fala com alívio do fato de estar num meio onde todos são gays, quando ela é heterossexual. Ressalto que lá ela é a diferente. Ela ri, concorda. Repete que lá ela é a diferente, mas que ninguém se importa com isso. Adèle não se recusa a dar testemunhos sobre sua família e sua vida, quando solicitada por organizações ou associações LGBT. Suas mães se preocupam com sua exposição. Mas Adèle acha muito importante poder falar de sua experiência de vida.

Segundo relatos ouvidos, o assunto homoparentalidade retorna com força neste momento ${ }^{23}$ na sociedade francesa, devido à discussão que acontece a respeito da revisão da lei da bioética, e que pode alterar as regras sobre a PMA. No entanto, as questões em debate se dirigem contra filhas e filhos e não contra mães e pais, como no caso do debate em torno do casamento.

Quando Rose foi entrevistada, sexta participante francesa, a questão dos impactos das manifestações francesas já fazia parte do universo de temas com potencial relevante para o estudo. Assim, quando o assunto não surgia espontaneamente, o tema era proposto:

Mônica - em 2013, qual era a sua idade?

Rose - 23 anos

Mônica - Eu imagino que você tenha ouvido muitas coisas sobre família homoparental...

Rose $-\operatorname{sim}$

Mônica - como você se sentiu?

Rose - as manifestações contra... me senti insultada, insultaram minhas mães, minha vida, nossa vida, ao mesmo tempo um sentimento... não de desgosto, mas de decepção. Pessoas que não entendem coisas que são normais.

\footnotetext{
${ }^{22}$ Instituto de estudos políticos de Paris.

${ }^{23}$ Período de setembro de 2017 à março de 2018, quando as entrevistas foram realizadas na França.
} 
Juliette, 45 anos, branca, viveu sempre com sua mãe e suas companheiras, mas mantendo contato com seu pai, relata não concordar com os ataques contra a família homoparental. Levanta questões relacionadas à busca das origens e o desejo de normalidade:

Mônica - sobre as manifestações contrárias ao mariage pour tous...

Juliette - Eu acho que há duas questões sobre isso, eu sempre digo: "Eu conheço meu pai e eu conheço minha mãe", então eu não sou, entre aspas, uma filha de um casal completamente lésbico, [ou seja] duas mulheres que decidem ter um filho, [...]. Eu sei de onde eu vim e esse assunto, eu sou incapaz de responder sobre os sentimentos de filhos que num dado momento... mas é a mesma coisa para filhos de sous $x^{24}$ e que vão procurar suas mães e sabemos que num dado momento procuramos de onde viemos... eu sempre disse, eu fui criada por uma mãe lésbica, isso não me causou nenhum problema. Eu vivo muito bem minha vida... existem muitos casais hetero, fazem filhos sem pensar, podemos ver o resultado. Você vê?! Para mim é só uma questão de identidade da origem, passando esse assunto aí, eu não sei por que um casal homo... eu não tenho problemas relacionados a isso e sobre o casamento eu não estou nem aí, bem, na minha opinião, cada um faz o que quiser [...]. Há também um desejo de normalidade [na busca pelo casamento] que se pode perguntar: Afinal, qual é o objetivo? Mas eu não sou contra ... Eu não me importo. Mas sou contra as pessoas que estavam na rua dizendo insanidades [...] é escandaloso... era mais isso que me aborrecia naquele momento [...].

Mathias, Adèle, Sophie eram jovens entre 14 e 17 anos em 2013 e Rose tinha 23 anos. Frequentavam na época escolas ou universidades e ouviam com frequência todo tipo de crítica de pessoas próximas, seus/suas próprios/as colegas, por vezes. Justamente com quem poderiam se solidarizar e encontrar apoio. Além disso, Adèle, Sophie e Rose não têm pai, foram concebidas por PMA com doador anônimo, e muitas das críticas contra aprovação da lei do mariage pour tous recaiam sobre a importância de se ter um pai e uma mãe e do quanto filhas/os sofreriam as consequências de uma criação fora da norma. Assim, as narrativas apontam o sentimento de agressão pessoal experimentado a partir de depoimentos e palavras de ordem pronunciados por opositores. Esse foi o impulso para que algumas/alguns filhas/os se envolvessem em projetos em prol da causa LGBT.

Juliette manifestou seu posicionamento contrário aos comentários "escandalosos" e destacou, justamente, que o (não) conhecimento das origens biológicas faz diferença na vida de filhas e filhos. Todavia, desvincula a questão referida, da orientação sexual de pai e mãe, lembrando do accouchement sous $x$. Sinaliza que conhece seu pai e sua mãe, o que a colocaria

\footnotetext{
${ }^{24}$ Abreviação de accouchement sous $x$, que significa a possibilidade de uma mulher deixar a criança que acaba nascer, aos cuidados dos serviços do Estado, e o direito de permanecer anônima aos olhos da sociedade. Procedimento permitido na França.
} 
em outra posição, diferente daquela em que se encontra algumas/uns filhas e filhos de pais e mães de mesmo sexo. Desta forma, não se identifica com sentimentos de filhas/os agredidas/os pelo olhar de uma sociedade. Não ocupa a posição de filha sem pai, situação tão criticada pelos contrários à legalização do casamento entre mulheres.

Como desdobramento das manifestações, Adèle e Sophie se sentiram impulsionadas a se envolver com a defesa da população LGBT. Mathias também se coloca disponível para participar de um projeto na Association des familles homoparentales (ADFH) ${ }^{25}$ onde poderá conversar com filhas/os de homossexuais, compartilhar suas experiências, uma vez que é o mais velho dentre eles/as na instituição. Marion, francesa de 23 anos, participou na luta pela promulgação da lei do mariage pour tous ao dar seu depoimento na Assembleia Nacional. Marion é preta, foi adotada no Haiti quando criança e criada por suas duas mães na França.

$\mathrm{Na}$ opinião de Isadora, mãe lésbica francesa ${ }^{26}$, a situação evoluiu bastante na França. Ela acha que, hoje em dia, tem muito menos preocupação que seu filho de 8 anos sofra preconceito do que tinha há anos, e comenta o seguinte:

Isadora - na manif pour tous em 2012 e 2013, honestamente, foi a primeira vez na minha vida que eu senti a homofobia tão perto. Foi um período que eu não estava bem. Foi muito difícil, mas acho que isso já passou. De forma geral, na sociedade, está mais fácil... como acontece na escola, no médico, eu no meu trabalho, jamais tivemos problema, de fato. Nós tivemos sorte. Os pais e mães [dos colegas de seu filho] vêm buscar as crianças e quando abrem a porta ficam uns 30 segundos [olhando]... e me perguntam se sou a tia. Porque eles deixaram as crianças com Violette [sua excompanheira e, também, mãe de Henri] e sou eu que me ocupo de devolvê-los. Eu lhes digo que eu sou a mãe e.... mas depois [de alguns instantes, tudo fica bem]... nunca tivemos história de "eu não quero que ele conviva com essa criança, isso não é normal", jamais. Eu acho que a sociedade vai se organizar, eu espero que sim, de toda forma [...]. Mônica - você acha que a discussão vai voltar, por causa da revisão da lei da bioética que vai ser revista?

Isadora - não sei, honestamente, eu adoraria que mudasse [a lei da bioética], mas não creio. [...] ... quando Henri nasceu era o Nicolas Sarkosy o presidente, não imaginava que isso [promulgação da lei do casamento anos depois] seria possível na verdade.

Na França, foi possível saber de forma explícita, nas ruas e nas mídias, como uma parcela da sociedade rejeitava a ideia da família homoparental adquirir direitos reservados à família heteroparental, e muitas/os filhas/os, mães e pais vivenciaram tal rejeição como um ataque pessoal. A forma como a França debate e debateu a questão tem relação com o caminho

\footnotetext{
${ }^{25}$ Associação de famílias homoparentais.

26 Ainda que entrevistas com mães não fizesse parte do objetivo da pesquisa, alguns encontros com mães aconteceram e serviram como complemento para o tema abordado.
} 


\section{Nanduty}

ISSN:2317-8590

escolhido por ela na busca por direitos de gays e lésbicas. $\mathrm{O}$ caminho francês tem sido o legislativo, assim, antes que leis sejam ou não aprovadas, discussões acaloradas acontecem na Assembleia Nacional e no Senado, assim como na sociedade de modo geral, através das associações, escolas, universidades, entre outros. As vias de acesso para aquisição de direitos por gays e lésbicas foram bem diferentes no Brasil e na França e revelam um pouco das características dessas duas sociedades.

\section{OS DESDOBRAMENTOS NO BRASIL}

No Brasil, as/os filhas/os também ouviram e ouvem muitas coisas negativas sobre suas famílias. Contudo, o tipo de debate amplo, aberto e da magnitude dos ocorridos na França, quando da discussão sobre a lei do mariage pour tous e da revisão da lei da bioética, não fez parte do cenário brasileiro, até então. Talvez, por isso, a maioria das/os filhas/os brasileiras/os não tenha relatado sentimento de agressão direta, o que não quer dizer que haja menos preconceito e discriminação no Brasil, ou que os assuntos homossexualidade e homoparentalidade não esteja sendo discutido em diferentes esferas e ambientes, e que certas posições não provoquem disputas e discussões constantes.

Relatos das/os brasileiras/os que mencionassem incômodo que atingisse suas famílias vieram, geralmente, de salas de aula na escola ou universidade, de manifestações na internet e conversas entre colegas.

Ana, brasileira, 12 anos, preta, adotada, viveu alguns anos com sua mãe e companheira, até a separação do casal, diz o seguinte:

\footnotetext{
Ana - [...] tem muita gente que fica falando que não pode, que é feio...

Mônica - você escuta isso, mas é direcionado a você ou a outras pessoas?

Ana - a outras pessoas

Mônica - como é quando você escuta isso?

$[\ldots]$

Mônica - te incomoda quando falam sobre isso dessa forma?

Ana - às vezes sim
}

Carla comenta que costuma deixar seu ponto de vista quando percebe comentários contrários à prática homossexual:

Carla - [...] duas garotas da minha escola deram um selinho, e as garotas que eu ando falaram "meu Deus!". Eu só fiquei ouvindo, teve uma hora que uma delas falou assim: "Eu não gosto, mas tudo bem", aí eu falei: "Como assim?". A garota disse: "Eu nunca faria, dar um selinho na minha amiga, mas eu não acho legal". Eu disse: "Elas que estão dando selinho, você não tem que achar legal ou não". Aí ela tentou se defender que a 
questão era: "Elas estão namorando ou são amigas?". Aí eu falei que era um problema delas. Aí ela falou: "Mas eu nunca vou dar um selinho na minha amiga". Eu falei: "Então tá bom". Porque também a gente tem que aceitar que a pessoa não aceita o diferente, eu não posso eu fazer um preconceito nela porque ela não aceita. Então eu só boto o ponto de vista: "Eu não acho isso [sua opinião] legal".

Ainda que a colocação da colega de Carla não tenha sido uma agressão à família homoparental, um comentário que contém crítica à homossexualidade, faz com que Carla reaja e deixe seu ponto de vista.

Betina, brasileira, 18 anos, branca, sempre viveu com sua mãe e companheiras, mas mantem contato com o pai. Ela conta como se sentiu quando a bancada evangélica ${ }^{27}$ se pronunciou em relação ao que seria uma família:

$\mathrm{Na}$ verdade, foi quando a bancada evangélica alegou que família era pai, mãe e filho. E eu tava numa fase bem revoltante, eu tinha acho que em torno de 16 anos, foi em 2016. Quando eu vi aquilo ali eu falei: "Peraí, quer dizer que minha família não é família, o que eu tenho dentro de casa não é família? Não é isso!". E eu tava vendo muita gente no Facebook falando: “Tá certo”. Eu falei: “Gente, como assim? Não é!". Eu não pensei só na minha família. E aquele filho que a mãe morreu no parto? Ou que o pai faleceu quando era pequeno? Ele tá vendo isso, como vai reagir? E as crianças do abrigo? Elas têm ali a família delas. Mas então pra eles aquilo ali não é família? Eu fiquei revoltada por ver as pessoas criticando, eu falei: "Quer saber, chega!". Foi quando eu postei [falando da configuração de sua família], aí teve gente me excluindo.

Na situação mencionada por Betina houve declarações públicas em que políticos se utilizaram de conteúdo religioso para se manifestarem de forma contrária às famílias que não correspondem à norma, e receberam apoio de parte da população. Não foi uma discussão em nível nacional, contudo provocou fortes reações em Betina, que se sentiu atingida pessoalmente por um posicionamento excludente, defendido até por colegas.

Temas como a diversidade familiar, orientação sexual e correlatos estão longe de ser um consenso no Brasil. Tomemos como exemplo o projeto Estatuto da família ${ }^{28}$ e os Movimentos

\footnotetext{
${ }^{27}$ A bancada evangélica é um conjunto de políticos de diferentes partidos que são evangélicos. Essa frente parlamentar que compõe o Congresso Nacional brasileiro se mobiliza e se posiciona contrariamente à discussão de gênero, projetos pedagógicos e educativos que combatem qualquer tipo de discriminação de gênero e sexual.

${ }^{28}$ Trata-se de um projeto de lei (PL 6583/2013), em tramitação, que define regras e políticas públicas relacionadas à família com o objetivo de restringir a noção de família a uma configuração familiar: a união entre um homem e uma mulher ou por um homem ou uma mulher e seus/suas filhos/as. O texto do Estatuto foi elaborado com base no conceito de família que é previsto na Constituição Federal (CF). Segundo o art. $226, \S 3^{\circ}$ da CF, a família é a base da sociedade, formada pela união entre homem e mulher, ainda que o Supremo Tribunal Federal (STF), em 2011, tenha estendido os direitos dos casais heterossexuais aos casais homossexuais, reconhecendo a união entre pessoas do mesmo sexo como família.
} 


\section{Nanduty}

Brasil Livre (MBL) ${ }^{29}$ e o Escola sem partido ${ }^{30}$ defendidos por políticos, setores conservadores da sociedade e pelo presidente da república, que fez sua campanha baseado nesses valores.

No ano de 2018, três grandes temas relacionados à homossexualidade e afins ocuparam os jornais durante alguns meses no Brasil: a distribuição nas escolas, que não aconteceu, de um material produzido pelo Ministério da Educação (MEC) sobre combate à homofobia, inclusive com seu conteúdo gravemente distorcido; a discussão do PL122 $2^{31}$, sobre a criminalização da homofobia, que acabou sendo retirado de pauta $^{32}$; e a polêmica em torno da não utilização do termo "gênero" nos planos nacional, estaduais e municipais de educação.

Estes temas ganharam grande visibilidade, ainda que não digam respeito especificamente à homoparentalidade. Talvez no Brasil as expressões de ideias e pensamentos contrárias à população LGBT estivessem mais camufladas, tanto que durante a campanha para a escolha do atual presidente da república, que ocorreu em outubro de 2018, depois das entrevistas terem sido feitas, parte da sociedade se manifestou de forma contrária à união entre pessoas do mesmo sexo, estimulada por alguns comentários do então candidato. É provável que muitas/os homossexuais, assim como filhas e filhos tenham se sentido afetadas/os ao longo da campanha política que antecedeu as eleições presidenciais brasileiras, devido às declarações preconceituosas realizadas. Talvez mesmo as/os participantes das entrevistas. Foi possível observar um crescimento nas expressões de ódio, não só nas redes sociais, mas nas ruas do país, onde apoiadores do então candidato diziam que a partir das eleições a situação mudaria, numa referência à uma imposição violenta do conservadorismo. Houve até mesmo uma corrida aos cartórios por parte de casais do mesmo sexo para que legalizassem suas uniões antes da posse do novo presidente.

Carlos, 24 anos, branco, brasileiro, viveu com suas duas mães até o falecimento de uma delas. Ele foi o único dentre as/os brasileiras/os entrevistadas/os que, devido a sua história

\footnotetext{
${ }^{29} \mathrm{O}$ MBL se define como um movimento liberal e republicano e apresenta os seguintes objetivos: imprensa livre e independente, liberdade econômica, separação de poderes, eleições livres e idôneas entre outros. O MBL se apropriou de pautas ultraconservadoras, dentre elas: a luta contra o feminismo, a "ideologia de gênero", o "politicamente correto"; o apoio ao movimento Escola Sem Partido. O MBL ainda existe enquanto movimento, mas não com a força de quando surgiu, em 2014.

${ }^{30}$ Através do discurso de combate à chamada “ideologia de gênero", defendia a exclusão do debate sobre gênero nas escolas e, consequentemente, na esfera da vida pública em geral. Foi julgado inconstitucional pelo STF em meados de 2020.

${ }^{31}$ Sobre a tramitação do PL 122 e as disputas políticas em torno dele, ver a tese de Adélia Zimbrão: Igualdade de diferença em tensão: disputas travadas por reconhecimento de direitos na arena legislativa.

${ }^{32}$ A homofobia e transfobia acabaram por ser criminalizada em junho de 2019 pelo Supremo Tribunal Federal.
} 
familiar, vivenciou a manifestação de parte da opinião pública brasileira se posicionando especificamente contra sua família. Sua mãe biológica foi uma figura pública, artista conhecida nacionalmente e que faleceu quando Carlos tinha 8 anos de idade. Ele não chegou a conhecer seu pai porque este veio a falecer durante sua gestação. Suas mães já viviam juntas quando uma delas ficou grávida de Carlos, que foi criado por ambas desde seu nascimento. Houve uma disputa familiar inesperada pela sua guarda. Sua mãe não-biológica não possuiu qualquer vínculo legal com Carlos o que deu brecha para que um membro de sua família materna reivindicasse na justiça sua guarda. A referida disputa tornou-se notícia de jornal no Brasil, trouxe à tona uma discussão importantíssima e deu visibilidade à dupla maternidade lésbica e à questão dos vínculos legais entre as mães e a/s criança/s.

Carlos trouxe essas informações logo no início da entrevista:

[...] assim, eu só fui ver preconceito mesmo quando a Giovana morreu, quando a minha mãe Giovana morreu porque teve a guarda, a coisa tomou, foi pra mídia, aí eu vi, caramba! É só porque minha mãe é mulher que eu tô correndo o risco de não ficar com ela, sabe. Minha mãe é mulher, é óbvio, só porque sou filho de um casal homossexual que eu tô correndo o risco de não estar com a pessoa que me criou. Foi aí que eu vi que tinha um risco mesmo, só por ser lésbica, só por ser homossexual, [...].

Em um determinado momento da entrevista, quando mencionei que filhas/os francesas/es ${ }^{33}$ se sentiram diferentes aos olhos das pessoas, ou se sentirem mal por desconhecidos se posicionarem contra suas famílias, Carlos acrescentou o seguinte:

É, foi o que passei [...]. Mas todos os irmãos da Giovana apoiaram a gente, todo mundo menos o meu avô. Minha vó, ex-mulher dele também me apoiou, nos apoiou. E foi assim, eu nunca achei que [eu] fosse diferente, não foi nem isso que me estalou, que era diferente, era mais tipo: “Caraca, as pessoas não gostam!". Era mais isso. É isso que eu tô tentando explicar. Na minha cabeça foi sempre tudo muito claro, sabe, nunca teve nada velado [sobre sua história], as coisas foram sempre [...] o que me impactou [...] foi essa coisa que você acabou de falar, não conhecer e não gostar. Qual é o problema? Eu cresci assim, temos amigos, eu estudo, meus professores sabem. Inclusive minha escola sempre foi aberta a discussão.

Podemos cogitar que as pessoas não gostam porque desconhecem, por se diferenciar da norma estabelecida, ainda que não seja diferente no seu funcionamento. O que é especialmente tocante e surpreendente para os membros das famílias agredidas.

A disputa pela guarda de Carlos aconteceu no início dos anos 2000, quando não existiam direitos estabelecidos para a população LGBT no Brasil. Mas foi a partir dos ataques

\footnotetext{
${ }^{33} \mathrm{O}$ encontro com Carlos foi realizado após as entrevistas francesas terem sido feitas.
} 


\section{Nanduty}

ISSN:2317-8590

direcionados à sua família de duas mães, e por uma delas se tratar de pessoa conhecida, que acabou por mobilizar meio artístico e opinião pública, auxiliando o surgimento de manifestações favoráveis. Assim, em 2002, quando Carlos tinha aproximadamente 9 anos de idade, depois que o caso tomou uma grande repercussão, houve um acordo entre as partes e a tutela definitiva ficou com sua mãe Gabriela. A decisão foi inédita no Brasil, na época. De acordo com o juiz, o depoimento de Carlos foi decisivo. "Ele saiu do ventre de Giovana para os braços da Gabriela", disse a avó de Carlos, segundo a imprensa, após a tão aguardada decisão judicial. Durante a audiência, Carlos foi claro ao demonstrar seu desejo em ficar com a mãe, de acordo com notícias na imprensa. Ele conta:

Especificamente eu era muito novo aí, eu não entendia direito, eu lembro que, assim, minha mãe tentou me isolar dessa coisa da mídia, desse processo. Mas, assim, eu lembro disso, caramba, pô, [pensava]: "Por que meu avô quer me tirar da minha mãe", sabe? É porque são duas mães e eu lembro de [...] inventarem mentira: "Ah! Porque são duas mulheres, a casa é sexo e droga. Só tem isso", sabe. "O que que é droga?" Eu não entendia, mas eu via que gerava, porra, ódio a ponto de [...] querer me tirar da minha mãe, de eu ter que sair de casa e morar com um cara que eu não conheço, só porque ele é um cara, tá ligado? Foi mais isso, eu não compreendia também, eu era um moleque.

\section{O EXTRAORDINÁRIO ENQUANTO POTÊNCIA DE REINVENÇÃO}

As diferenças encontradas nas falas de francesas/es e brasileiras/os expõem certas especificidades das sociedades como os distintos caminhos traçados para buscar e adquirir direitos relacionados à população LGBT, e o momento político de cada uma à época das entrevistas.

Entretanto, um dos aspectos que chama atenção, nos dois países, é o quanto filhas e filhos saíram em defesa da família, algumas/uns atuando mais diretamente em prol das pessoas LGBT. Ainda que o elemento que torna suas famílias alvo de ataques e vulneráveis legalmente seja a homossexualidade de suas mães, parecem esvaziar a questão e sobrepor a parentalidade à sexualidade delas no cotidiano em família e na construção de fortes vínculos.

A orientação sexual de suas mães é vista socialmente como o detonador de conflitos, porque carrega rótulos e revela verdades. Resultando, assim, em tratamento desigual e subtração de direitos, marcando uma diferença perante a sociedade. Diferença que inferioriza, uma vez que a homossexualidade estaria fora de um "sistema de valores sexuais, segundo o qual a sexualidade 'boa', 'normal' e 'natural', seria a heterossexual, marital, monogâmica, reprodutiva e não comercial" (Rubin, 1989: 21). Sendo a homossexualidade, então, considerada anormal e antinatural. 
O "amor que é famoso por não ousar dizer seu nome", como nos lembra Sedgwick (2007, p. 21), continua a perturbar e é percebido como algo a ser mantido em segredo por alguns/algumas ou revelado por outros/as ${ }^{34}$. Ainda segundo a autora, "o armário gay não é uma característica apenas das vidas de pessoas gays" (2007, p. 22), assim, a partir do conhecimento sobre a orientação sexual de sua/s mãe/s, as/os filhas/os entrariam no "armário". Com isso, diferentes repertórios de comportamentos são desenvolvidos e colocados em prática, estratégias são criadas e o "armário", enquanto dispositivo de regulação proposto por Sedgwick (2007), pode ser utilizado de múltiplas formas, e não imposto como única maneira de se viver a homossexualidade.

Foucault (1988) vai propor um olhar sobre as verdades da sexualidade, propor a análise da formação de um certo tipo de saber sobre o sexo. Verdades e saberes esses, partes integrantes de um dispositivo de controle, cuja relação não se faz somente com a lei ou com a repressão e sim com o poder.

E quanto ao poder, Foucault (1988: 102) esclarece:

[...] não o entendo como um sistema geral de dominação exercida por um elemento ou grupo sobre outro e cujos efeitos, por derivações sucessivas, atravessem o corpo social inteiro. A análise em termos de poder não deve postular, como dados iniciais, a soberania do Estado, a forma da lei ou a unidade global de uma dominação; estas são apenas e, antes de mais nada, suas formas terminais.

Assim, a menção de Foucault às relações de poder diz respeito às encontradas em quaisquer relações humanas, de diversas formas, diferentes níveis, e que são móveis e reversíveis. Sobre as resistências, nunca estão "em posição de exterioridade em relação ao poder" (Foucault, 1988: 105). Existindo poder, existem resistências:

[...] são, portanto, distribuídas de modo irregular: os pontos, os nós, os focos de resistência disseminam-se com mais ou menos densidade no tempo e no espaço, às vezes provocando o levante de grupos ou indivíduos de maneira definitiva, inflamando certos pontos do corpo, certos momentos da vida, certos tipos de comportamento (Foucault, 1988: 106).

Os embates descritos ao longo do texto são talhados de poder e resistência, já que o poder não se encontra em um determinado local, mas é uma prática social historicamente construída. Ele se exerce e está distribuído em toda organização social, não tem um lugar

\footnotetext{
${ }^{34}$ Sobre como filhas/os lidam com "segredos" e "revelações" da homossexualidade das mães em suas relações sociais, ver Pontes (2019), onde o assunto é tratado com mais profundidade.
} 
específico (Foucault, 2010). Só existe em ato, na relação; sendo ele ação sobre ação (Foucault, 1995), o poder se exerce em rede, circula, funciona em cadeia.

Os movimentos conservadores reagem quando a população LGBT adquire direitos. Tal reação de setores da sociedade impulsiona jovens filhas/os de famílias homoparentais na defesa de suas famílias:

É mais comum, entretanto, serem pontos de resistência móveis e transitórios, que introduzem na sociedade clivagens que se deslocam, rompem unidades e suscitam reagrupamentos, percorrem os próprios indivíduos, recortando-os e os remodelando, traçando neles, em seus corpos e almas, regiões irredutíveis. Da mesma forma que a rede das relações de poder acaba formando um tecido espesso que atravessa os aparelhos e as instituições, sem se localizar exatamente neles, também a pulverização dos pontos de resistência atravessa as estratificações sociais e as unidades individuais (Foucault, 1988: 107).

Certamente, não fossem famílias de mães lésbicas, essas/es filhas/os não estariam implicadas/os nessa história. Mas quando filhas e filhos tomam a palavra em favor de suas mães, numa conversa com colegas, em manifestações nas ruas, em depoimentos públicos, através de relatos indignados, de participações em associações ou da expressão de suas histórias, concordando em compartilhar suas vidas em pesquisas acadêmicas ou na mídia, essas/esses filhas/os pretendem respeito, reconhecimento e proteção para suas famílias, estão exercendo poder e estão resistindo. Reinventam o viver e resistem ao movimento de assujeitarse (Borges, 2019).

\section{CONSIDERAÇÕES FINAIS}

A prática homossexual e a percepção que as sociedades têm da homossexualidade, e consequentemente da homoparentalidade, dizem respeito a distintas dimensões da sexualidade. Enquanto prática sexual, a homossexualidade não aparece como temática familiar, entre filhas/os e mães nas famílias aqui retratadas, assim como não é costume que o seja nas demais famílias, de modo geral. A maternidade se sobrepõe, independentemente da orientação sexual das mães, no exercício doméstico, além da dimensão da privacidade que o assunto sexualidade porta. Ninguém questionaria o fato de a sexualidade de pais e mães heterossexuais não ser tema de conversa em família. Geralmente é um assunto privado e, até mesmo, interditado. Sob esse prisma, as narrativas de filhas e filhos apontam o quanto suas mães são mães como as outras e suas famílias são famílias como as outras. 


\section{Nanduty}

Contudo, nas famílias homoparentais o tema sexualidade atravessa seus cotidianos, devido à homossexualidade das mães. Ainda que não falado enquanto prática e intimidade sexual, em ambiente familiar, a sexualidade enquanto reguladora e detentora da verdade estabelece padrões. Há a sexualidade certa e há as desviantes. O olhar social carregado de preconceito é que transforma essa família em diferente.

Além disso, há uma expectativa de que filhas/os saibam sobre a homossexualidade de suas mães. A sociedade introduz uma espécie de exigência de que essas crianças sejam orientadas, pelas mães e pais, sobre a homossexualidade delas/es. Sendo assim, espera-se que, de certa forma, seja um assunto de família, uma vez que isso significaria preparar, oferecer ferramentas a essas crianças e jovens para eventuais discriminações, comentários e até mesmo agressões direcionadas às suas famílias. Isso representaria cuidado parental para que filhas/os possam desenvolver estratégias de defesa e enfrentamento.

Filhas/os se movimentam entre o ser igual e diferente de suas famílias. Igual porque sexualidade de mãe pouco interessa, é a parentalidade que importa. Diferente porque a sexualidade prevalece em sociedades em que é o sexo que fala da pessoa.

A fundamental luta por direitos dá visibilidade à família homoparental, mas também evidencia opositores e suas ideias conservadoras. Visibiliza a polêmica. A discussão precisa ser feita pela sociedade, mas há um custo e ele é sentido pelas/os filhas/os. Nada parece banal quando parte considerável da sociedade torna público seus pensamentos e impressões sobre famílias de mães lésbicas. Filhas/os deslocam-se do ordinário do cotidiano familiar e encaram o extraordinário no qual estão emaranhadas/os. Se tal deslocamento ficou mais evidente através das narrativas francesas, muito se deveu aos debates públicos que precederam à lei de 2013, reatualizados em 2017, devido à possibilidade de abertura da PMA para todas.

O caminho legislativo escolhido pelos franceses, na busca por direitos LGBT, é distinto do caminho judiciário, percorrido pelo Brasil. Algumas decisões brasileiras foram tomadas por um grupo de ministros, não ocorreram através do envolvimento da população, nem geraram um grande debate em âmbito nacional. Todavia, o Brasil de 2018 para cá, vem expondo claramente sua face mais conservadora. Caso filhas e filhos de famílias homoparentais fossem ouvidas/os nesse período, as narrativas talvez apontassem maior incômodo pelo que políticos e apoiadores de uma agenda de costumes vêm verbalizando sobre suas famílias.

Envolvida nesses ditos e não ditos, a sexualidade é algo do qual não se fala, ao mesmo tempo que dela se fala o tempo todo. Falar ou não falar sobre parece estar a serviço também do 


\section{Nanduty}

ISSN:2317-8590

dispositivo da sexualidade, numa sociedade da qual um dos emblemas é o sexo, o "sexo que fala" (Foucault, 1988: 87).

Diante disso e tomando como inspiração Hélia Borges (2019: 33) ao questionar o corpo fabricado, "produzido e perpetuado pela família nuclear", essas/es filhas/os resistem e, conforme Rolnik (2014), criam mundos. Pendulam entre a banalidade, no sentido do que é comum, e o extraordinário, no sentido do admirável. Atravessam códigos deformando-os e afirmam as vidas em seus desvios (Borges, 2019).

\section{REFERÊNCIAS BIBLIOGRÁFICAS}

BORGES, Hélia. 2019. A clínica contemporânea e o abismo do sentido. Rio de Janeiro: 7 letras. BORRILLO, Daniel. 2010. Homofobia: História e crítica de um preconceito. Belo Horizonte: Autêntica.

CADORET, Anne. 2014. Des parents comme les autres. Homosexualité et parenté. $2^{\mathrm{a}}$ ed. Paris: Odile Jacob.

CÔTÉ, Isabel et al. 2019. "Récits d'enfants sur leur constellation familiale: les liens relationnels au sein des familles lesboparentales avec donneur connu au Québec". Devenir, 2 (31): 125143.

DAVIS, Erin.; FRIEL, Lisa. 2001. "Adolescent sexuality: disentangling the effects of family structure and family context”. Journal of marriage and family, n. 63, p. 669-681.

DELEUZE, Gilles.; PARNET, Claire. 1998. Diálogos. São Paulo: Escuta.

DIAS, Maria Berenice. 2009. União homoafetiva: o preconceito \& a justiça. 4. ed. São Paulo: Ed. Revista dos Tribunais.

FASSIN, Eric. 2008. L'inversion de la question homossexuelle. Paris: Éditions Amsterdam.

FLAKS, David. et al. 1995. "Lesbians Choosing Motherhood: A Comparative Study of Lesbian and Heterosexual Parents and Their Children". Developmental Psychology, 31 (1), p. 105-114. FOUCAULT, Michel. 1988. História da Sexualidade 1: A vontade de saber. São Paulo: Graal. FOUCAULT, Michel. 1979. Microfísica do poder. Rio de Janeiro: Graal.

FOUCAULT, Michel. 2010. Em defesa da sociedade. São Paulo: WMF Martins Fontes.

GROSS, Martine. 2013. Parent ou homo, faut-il choisir? Idées reçues sur l'homoparentalité. Paris: Le cavalier bleu.

FULCHER, Megan.; SUTFIN, Erin.; PATTERSON, Charlotte. 2008. "Individual Differences in Gender Development: Associations with Parental Sexual Orientation, Attitudes, and Division of Labor". Sex Roles, n. 58, p. 330-341.

GOLDBERG, Abbie. 2007. "(How) Does It Make a Difference? Perspectives of Adults with Lesbian, Gay, and Bisexual Parents". American Journal of Orthopsychiatry, 77 (4), p. 550-562. GOLOMBOK, Susan.; SPENCER, Ann.; RUTTER, Michael. 1983. "Children in lesbian and singleparent households: psychosexual and psychiatry appraisal". J. Child Psychology Psychiatry, 24(4), p. 551-572.

GOLOMBOK, Susan et al. 2003. "Children with Lesbian Parents: A Community Study". Developmental Psychology, 39(1), p. 20-33.

hooks, bell. 1984. Feminist theory from margin to center. Cambridge: South End Press. 
MACCALLUM, Fiona; GOLOMBOK, Susan. 2004. "Children raised in fatherless families from infancy: a follow-up of children of lesbian and single heterossexual mothers at early adolescence". Journal of psychology and psychiatry, n. 45, p. 1407-1419.

PONTES, Mônica. 2019. Filhas e filhos de mães lésbicas: caminhos e margens no Brasil e na França. Tese de Doutorado em Psicologia Social, Universidade do Estado do Rio de Janeiro, UERJ.

RABINOW, Paul; DREYFUSS, Hubert. 1995. Michel Foucault. Uma trajetória filosófica. Para além do estruturalismo e da hermenêutica. Rio de Janeiro: Forense Universitária.

ROLNIK, Sueli. 2014. Cartografia sentimental, Porto Alegre: Meridional e Editora da UFRGS. ROZÉE, Virginie. "L'homomaternité issue de l'assistance médicale à la procréation en France: état des lieux d'un recours transnational". In: BORRILLO, E. ; FASSIN, E. (dir.). Dossier "La bioéthique en débat: angles vifs et points morts". Raison Publique: Presses universitaires de Rennes, 2012. Disponível em : <http://www.raison-publique.fr/article531.html >. Acesso em: 20 fev 2018

RUBIN, Gayle. 1989. "Reflexionando sobre el sexo: notas para uma teoria radical de la sexualidade". In: VANCE, Carole. (org.). Placer y peligro: explorando la sexualidad femenina. Madrid: Revolución, p. 113-190.

SEDGWICK, Eve. 2007. “A epistemologia do armário”. Cadernos Pagu, n. 28, p. 19-54.

TEDESCO, Silvia.; SADE, Christian.; CALIMAN, Luciana. 2013. "A entrevista na pesquisa cartográfica”. Fractal, Revista de Psicologia, 25(2), p. 299-322.

VANFRAUSSEN, Katrien; PONJAERT-KRISTOFFERSEN, Ingrid; BREWAEYS, Anne. 2002. "What does it mean for youngsters to grow up in a lesbian family created by means of donor insemination?". Journal of reproductive and infant psychology, 20(4), p. 237-52.

VECHO, Oliver. ; SCHNEIDER, Benoît. 2005. "Homoparentalité et développement de l'enfant : bilan de trente ans de publications". La psychiatrie de l'enfant, Paris, 48(1), p. 271-328.

WAINRIGHT, Jennifer; RUSSEL, Stephen; PATTERSON, Charlotte. 2004. "Psychosocial Adjustment, School Outcomes, and Romantic Relationships of Adolescents With Same-Sex Parents". Child Development, 75(6), p. 1886-1898.

WAINRIGHT, Jennifer; PATTERSON, Charlotte. 2006. "Delinquency, Victimization, and Substance Use Among Adolescents with Female Same-Sex Parents". Journal of Family Psychology, 20 (3), p. 526-530.

ZAMBENETETTI, Gustavo.; SILVA, Rosane. 2011. "Cartografia e genealogia: aproximações possíveis para a pesquisa em psicologia social”. Psicologia \& Sociedade, 23(3), p.454-463.

ZIMBRÃO, Adélia. 2018. Igualdade de diferença em tensão: disputas travadas por reconhecimento de direitos na arena legislativa. Tese de Doutorado em Psicologia Social, Universidade do Estado do Rio de Janeiro, UERJ. 